\title{
Review of Susan Trevaskes, Policing Serious Crime in China: From 'Strike Hard' to 'Kill Fewer'
}

\author{
Oxon: Routledge, 2010. \\ ISBN: 9780415564472, 240 pages, $\$ 125.00$ (hardcover)
}

\section{Jianhua Xu}

Received: 8 January 2012 / Accepted: 31 January 2012 /

Published online: 28 February 2012

C The Author(s) 2012. This article is published with open access at Springerlink.com

The past three decades have witnessed great transformations in all aspects of Chinese society. As the most populous nation and the second largest economy in the world, China's experience of crime and the government's way of handling crime provide unprecedented opportunities for social scientists in general and criminologists in particular to accumulate knowledge and develop theories. The increasing crime rates caused by the rapid process of industrialization, urbanization, and modernization in China provide fascinating opportunities for criminological research. However, existing criminology literature, both within Chinese academia and in the English world, is still underdeveloped. Susan Trevaskes' book Policing Serious Crime in China: From 'Strike Hard' to 'Kill Fewer' is an important and timely contribution to the field.

In this book, Trevaskes skillfully examines the politics, practice, procedures, and public perceptions of yanda anti-crime campaigns in the first 25 years of the post-1978 reform period. Trevaskes develops the concept of campaign policing and justice in China in order to describe the Chinese criminal justice practice to punish criminals "harshly and swiftly" in response to an increasing crime rate since the start of its economic reform in the 1980s.

According to Trevaskes' analysis, the anti-crime campaigns take two forms depending on the scale. One is a nationwide strike hard (yanda) campaign, which can last up to three years and target a variety of crimes; the other is "specialized struggle" (zhuanxiang douzheng), which uses "strike hard" policy to target a specific category of crime and lasts for a relatively short period of time, usually three to six months. Campaign justice becomes the most typical response by the Chinese Party-state to deal with crime. Since 1983, there has been no single year without a yanda campaign or "specialized struggle" in China. During campaigns, three agencies of criminal justice - the police, the procuratorate, and the court-make a concentrated effort over a specified time period to attack targeted crimes "severely and swiftly". Due process is often neglected, while abuse of human rights and confession by torture

J. Xu $(\bowtie)$

Department of Sociology, University of Hong Kong, Rm. 1208, K.K. Leung Building, Pokfulam,

Hong Kong

e-mail: ajianfly@gmail.com 
become common practice. As the author rightfully points out, the rationale for campaign justice is order-stability, not human rights (p.1).

The author particularly focuses on the political culture that shapes the rise and fall of the campaign justice. She convincingly argues that the culture of campaign justice is based on the Maoist ideology of political struggle (p.2). Facing the outbreaks of serious crimes in the early 1980 s, the Party-state resorts to its familiar way of handling social problems: campaigns (p.75). The author argues that campaigns become vehicles through which the yanda policy made by the central government is disseminated and realized at the local level. While yanda's parentage is the mass movement of the $1950 \mathrm{~s}$, the son of yanda is "specialized struggle".

However, campaign justice started to wane in the first years of twenty-first century. The effectiveness of the 2001-2003 national yanda campaigns, for instance, came under serious questioning. Many local and even national top police officials publicly criticized the abuse of human rights and the ineffectiveness of controlling of crime through these campaigns. Some scholars even argued that yanda actually contributes to increasing, rather than decreasing, crime rates (p.79). In 2003, the Party-state's rhetoric started to emphasize that yanda should be "regularized" in everyday police practice. The author argues that the subtle shift in terminology from an emphasis on yanda as a discrete "political struggle" to one of "regularization" marks a turning-point of campaign justice's fall.

Indeed, as the author argues, Chinese criminal justice proves to be pretty harsh. Although the actual number sentenced to the death penalty still remains a state secret, the general estimation is that more people are executed for crime in China each year than in the rest of world combined. In recent years, Chinese authority's response to crime is under reform and has become less punitive. In 2007, the Supreme People's Court reclaimed its review rights on all death penalty cases from Higher People's Court, which incurred a sharp reduction of death penalty, a one-half and even two-thirds decline as some Chinese legal scholars have estimated. The author has rightfully summarized this trend as "from 'strike hard' to 'kill fewer'."

However, I am not as optimistic as the author regarding her speculation that the future of campaign justice will "most probably disappear in the decade ahead" (p.178). If we agree with the author's judgment that "strike hard" is fundamentally political, and political deployment is much more important than fighting crime, then under the current Party-state's top priority of "maintaining social stability", the anticrime campaigns could still be utilized by the government to remind people that social order is still in their control. The high profile anti-organized crime campaign in Chongqing since 2009 is a good example in that regard. The optimistic judgment on the end of campaign justice might be related to the author's over-reliance on secondhand data from newspapers and the Party-state's official discourse (e.g., Xiao Yang's words (p.176) and official crime statistics on the stabilization of the crime situation).

In addition, to some extent, chapters 5 and 6 are not well integrated with the whole book. While the book's theme is "policing serious crime", these two chapters are more about the situation of drugs and organized crimes rather than how the Party-state polices and manages them. As the author herself points out, "the following two chapters put the spotlight on crime rather than on crime control" (p.164). Despite this admission, these chapters remain only loosely tied to the central thesis of the book.

The author raises other issues that are also difficult to agree with. Trevaskes argues that 2003 marked the turning-point from the "strike hard" to "kill fewer" campaigns, as the 
Party-state started to emphasize "regularization" of yanda in everyday police practice. However, 2007 might indicate a much clearer turning-point, as the Supreme People's Court's reclaiming of review power on the death penalty caused a dramatic decline in those sentenced to the death penalty, killing fewer. Moreover, I hesitate to agree with the author's observation that "police statistics in the early 1980s were much more accurate than they are today" (p.3).

Nevertheless, this book is an important contribution to Chinese criminology. It will also be of interest to readers in China studies, sociology, and political science in general.

Open Access This article is distributed under the terms of the Creative Commons Attribution License which permits any use, distribution, and reproduction in any medium, provided the original author(s) and the source are credited. 